\title{
Biblical spirituality, thematically approached: methodological considerations around 'discernment'
}

\begin{abstract}
In this paper on methodology, dedicated to Vincent Brümmer, the nature of Biblical Spirituality as nascent academic discipline is summarised as facing two ways: that of the ancient biblical text, and that of the modern person engaging with the Bible - in both instances with an explicit interest in matters of faith. Discernment is chosen as a topic around which in this way to explore the methodology of the discipline of Biblical Spirituality, expanding on the influential work of McGrath in this regard, but also linking to the recent research interest in this topic, in addition to discernment by its inherent nature being topical for the methodology and the identity of the discipline of Biblical Spirituality.
\end{abstract}

\section{FOR VINCENT BRÜMMER}

It is an honour to dedicate this study to the life and continued work of Vincent Brümmer, who has over decades been one of the internationally most recognised faces of South African theological scholarship. To pay tribute to him from the perspective of the discipline of Christian Spirituality is particularly apt: much of Brümmer's work (e.g. Brümmer 2010:1-5, 2006:317-331, 1992 and more popularly: Brümmer 1988) has been of great importance to the discipline. He has been involved both personally with leaders of the Spirituality Association of South Africa (SPIRASA) and institutionally, with his work having been formally reviewed at a special SPIRASA meeting in which he participated. Personally, I remain grateful too that, though I am still a relative newcomer to the discipline of Christian Spirituality, he had sought me out in Pretoria to discuss prayer in preparation for what would become his prize-winning Wat doen ons wanneer ons bid? Oor die aard van gebed en geloof (2011; cf. its precursors Brümmer 1984 \& 2008). It is thus with great appreciation for his person and work that I dedicate this study to Vincent Brümmer.

\section{BIBLICAL SPIRITUALITY: ITS TWO FACES / MIRRORS / OUTLOOKS}

The academic discipline of Biblical Spirituality has a valuable contribution to make in analysing the ways in which people relate and relay their lives in an understood relationship with the Bible. Precisely because of its methodological situatedness somewhere between the refined exegetical techniques of Bible scholarship and the broader, more vague approaches of the Spirituality discipline (cf. Lombaard 2011:211-225), Biblical Spirituality faces two ways. The one outlook of the discipline is historical, namely on the spiritualities that came to be reflected in the biblical texts; the other outlook is experiential, namely on later, including modern, spiritualities as they relate (themselves) to these Scriptures. This dual outlook is an emerged consensus within Biblical Spirituality on its disciplinary vantage point (cf. such publications as Lombaard 2012b; De Villiers \& Pietersen 2011; Agnew 2008:187-197; De Villiers, Kourie \& Lombaard 2008; De Villiers, Kourie \& Lombaard 2006; Schneiders 2005:1-22 \& 1999; Waaijman 2004; Nolan 1982.) How faith found reflection, historically, in antiquity within the texts that would later become Scripture, and 
how, existentially, people throughout the ages, including in our time, had related and continue to do so with these Scriptures, these two (associated) aspects are the duel mirrors facing one another between which the discipline of Biblical Spirituality finds itself, making observations of a phenomenological, analytical, evaluative, critical and suggestive nature.

Thus, the analytical-historical and the contemporary-experiential aspects of the text-reader interaction (cf. Waaijman 2011:1-20) find a shared, if not entirely unproblematic (Lombaard 2011:211-225), home within the discipline of Biblical Spirituality. Though Biblical Spirituality is not unique in occupying such a position, with for instance History or Literature often finding themselves at similar intellectual stations, the esteem in which the collection of Bible texts are held by those who experience God as addressing them through this canon, adds to this hermeneutic dynamic a particular existential urgency. The latter holds true for many professional exegetes (Lombaard 2012a) and for almost all Bible readers, giving rise within the study field of Spirituality to the formal recognition (e.g. Hanson 1990:50) of what has become known as the self-implicatory nature of both the discipline of Spirituality and, more directly or automatically or unreservedly, the lived phenomenon (cf. e.g. Ruthenberg 2005:134-136) of spirituality.

It is from within this dual facing position of Biblical Spirituality that it is important to analyse methodological aspects of the way in which themes may be addressed, namely as they are sought within the holy library of the Bible in order to be related to their lives by, usually, religiouslymotivated readers and exegetes. The most well-known modern impetus to such a thematic approach to the to-and-fro of text-and-reader within the discipline of Biblical Spirituality, is found in the work by McGrath (1999:82-109), in which he analyses a series of themes from the Bible and then indicates thematically-related parallels from the history of and the writings on Christian spirituality throughout the ages. The assumption underlying such analyses, with McGrath but also across the discipline of Biblical Spirituality, is that sustained, fuller, more existentially-profound meaning can be found from the Bible if material from it can be shown, and experienced, to be of continued personal and social religious relevance, namely in parallel, analogical, reinterpreted ways.

The themes McGrath had chosen, were: feast, journey, exile, struggle, purification, internalisation, desert, ascent, darkness and light, and silence. Ranging from more concrete to more abstract themes, and covering - apart from illustrative thematic parallels from the history of Christian spirituality - both the Old and New Testaments, McGrath offers, in brief, insights into how such an approach may be developed. Because of the more general, introductory nature of that publication, McGrath does not go into the details of exegesis of each occurrence of the theme, within its textual and historical contexts, then tracing the line of interpretations and reinterpretations as they developed historically throughout the period in which the biblical texts had come into being - the influential traditionsgeschichtliche method of exegesis most famously practiced by Von Rad (cf. especially his Old Testament Theology, most particularly the first volume - Von Rad 1962). Nor does McGrath trace in great detail the post-canonisation Wirkungsgeschichte of each theme throughout the subsequent interpretational history (cf. e.g. Janowski \& Stuhlmacher 2006), so important for latter-day theological hermeneutics. Rather, McGrath implicitly draws on these intellectual impulses, in order to facilitate a more existential, faith-(in)forming analysis of themes as an expression of the discipline of Biblical Spirituality: how the theme had developed with the texts of the Scriptures, and how the theme had been treated by some classical interpreters (cf. Waaijman 2011:1-20 for a recent insights along these lines). The further value of McGrath's contribution lies in its suggestive nature, inviting as it does further reflection and more detailed exegesis-interpretation in similar vein.

Because of recent advances in the way the communication of the biblical texts, internally among themselves and hence, implicitly, with their readers, are understood, a more complex 
text-reader communicative interaction must now be made room for. It is with respect to such developments that further reflection will be offered in what follows. This is done not in relation to any of the themes already identified by McGrath (1999:82-109), listed above; rather, that list is expanded to include a theme which has drawn considerable research interest of late, namely discernment.

This contribution therefore forms part of a trilogy of studies on the topic of discernment (the other two being Lombaard 2012/2013a and 2012/2013b), resulting from particularly a Biblical Spirituality "Experts Meeting on the Spirit and Discernment in Hebrew and Christian Scriptures", which took place at the Carmelite Institute Mdina, in Malta, late in May 2012, but drawing also on the "Religious Experience and Tradition International Interdisciplinary Conference" held at the Vytautas Magnus University, Kaunas, Lithuania, during mid May 2012. It is particularly in the publication resulting from the latter that a definition on discernment was concluded to; that definition is repeated here for the sake of clarity (for the argumentation leading up to it, cf. Lombaard 2012/2013a):

Discernment is the process or event of Divine-human interaction in which the Holy will on certain key matters are (sought and) conveyed to the person/s involved, usually in an everyday manner, but which may at the same time take on a raised awareness of profound magnitude. In whichever case, the person/s, their closer circles and broader society find themselves altered toward a greater state of wellbeing, living a more deeply meaningful, fulfilling life in the light of the Divine guidance (sought and) found.

Discernment thus understood will in the rest of this contribution be the illustrative theme around which matters pertaining to the discipline of Biblical Spirituality are discussed. Not a full Biblical Spirituality of discernment is offered here. Rather, the more modest goal of describing two methodological concerns en route to such a broader endeavour is set for the remainder of this contribution. Neither is the focus here on the biblical side yet (that, in Lombaard 2012/2013b), but the discussion is on the interpretative / interpretational (cf. Brümmer 2010:1), one of the outlooks of the discipline of Biblical Spirituality.

We therefore turn next to such a methodological consideration of two aspects of the ways in which discernment of the divine will is encountered or gleaned from (and not in, yet) the Hebrew Scriptures: first, the choice of Testament, and second, the way in which the communication between biblical text and reader is viewed.

\section{DISCERNMENT AND THE UGLY DUCKLING TESTAMENT}

The choice of the first Testament among the Scriptures around which to structure a discussion on discernment, is a minority position within scholarship: always, in works on discernment and the Bible, it is the New Testament that is treated more extensively (Moberly 2006:15; cf. e.g. Schweizer 1989:406-415). For this, there are many good reasons, chief among which is the natural preference within Christianity for the Greek collection in the Bible, which deals directly with Jesus. Furthermore, when it comes to a theme such as discernment, the key texts providing the terminological impetus for this topic, are from the New Testament (for overviews of the reception history of the foundational text on "discernment of spirits", 1 Corinthians 12:10, cf. e.g. Bertrand 2003:487-451, Lienhard 1980:508-329; more broadly, treating mostly Pauline texts, cf. Munzinger 2007, Johnson 1996).

This emphasis on the newer Testament has effects such as that, often when discernment and the Hebrew Bible is discussed, the meaning of discernment is for the most part restricted to the issue of distinction among modern scholars between true and false prophecy (so e.g. Anderson 2011:17-20, Moberly 2006); or that Greek/Hellenistic thought is read into the Semitic 
worldview of the Old Testament (a methodological concern also noted by Berthoud 2010:54). An example of this is when the idea of "discernment of spirits" is applied to Hebrew Bible texts that, on the sound of it, seem to refer to "the spirit of God" (e.g. Guillet 1970:17-26; cf. Panicola 1999:730-731), however with the point neglected that "spirit" has strongly different connotations in the Old Testament (cf. Vosloo 1983:40-68), namely as something of a "creative power of God" (Schweizer 1989:406-408, 413; cf. Ukpong 1989:418-419), to what we find in the New Testament, with its ideas on - broadly - the Spirit as a continued though altered personal presence of the elevated Christ among the Jesus followers.

As a methodologically more valid stance, the religion of Israel ought to be treated on its terms, from within its own historical contexts, as these developed onward with the passage of time, rather than retro-projecting later concepts from the Christian era onto, for instance, post-exilic Israel. It must be accepted, until proven differently, that the idea of discernment as encountered in the New Testament is not directly present in the Old; yet, in some ways "central themes of discernment" (Panicola 1999:730), in their own manner, are.

The entry point for any further exploration of this matter, true to the nature of the discipline of Biblical Spirituality, ties in with the way in which the Bible is viewed, or rather, experienced, by the religious readers of this canon. In what follows, this aspect is taken into further consideration, with a particular eye on three notions within the modern era on the way the Bible communicates with its readers.

\section{THE BIBLICAL TEXT, ALIVE AND... WELL... ON TEXT-READER COMMUNICATIVE INTERACTION}

Modern readers view the way in which the biblical texts are thought to reflect ideas and proposals for them, in a variety of ways. The view to which is subscribed in this respect "subscribed", though, seldom in an intellectually analytical way, but usually through a growing, lived experience - has on its part direct bearing on the way in which the Bible is employed by its readers to come to their life decisions - "employed", though, seldom in a purposely instrumentalist way, but usually through, again, a growing, lived experience. Among the views on the way the Bible contains, reflects and conveys ideas, count three, which may be titled the hard-and-fast understanding of the communication of the Scripture with its readers, the optimistic pessimist's way and communication as an arena of contestation. Each of these views will now be described, with its implications for spirituality in general and for discernment in particular indicated.

\subsection{Hard-and-fast}

In this understanding of the Bible, most commonly found among conservative/traditionalist Bible readers, the Scriptures contain a treasury of ideas that was indeed written down by humans, but which really came about as a more or less direct communication from God. Accompanying this is a strongly literal theory of biblical inspiration (cf. Malley 2004:147-151), so that the faithful may truly believe that they see and read God's words on these pages. Any problems the reader or scholar within such an approach may detect in the texts of the Bible, such as seeming contradictions or apparently illogical repetitions in the texts (with the Genesis 12, 20 and 26 "my wife - my sister" narratives as a good example from the Old Testament, or the various accounts of Jesus' life in the Gospels in the News Testament) or inconsistencies and inaccuracies (ascribable to human error, or to cultural and worldview differences between ancient and modern civilisations on e.g. creation, or to literary genre) are thus merely the result of our human inadequacies: we do not understand the Bible well enough. Hard work, guidance by the Holy Spirit, and even conversion will in time solve such frailties on our part, and we shall 
then see that we simply had not understood the text well enough yet (cf. Dubay 1997:186-204; Howard 2000:15). The Bible itself is a divine oracle of sorts, free of even the possibility real error.

Such an understanding of the firmly-set or "hard" nature of the holy text enables a biblicistic use of the Bible, of which the dicta probantia form of argumentation is one characteristic. Here, "fast" answers can be arrived at - in both senses of the term: the truths are firm, and they can be obtained quickly (what Horton 2009:8-9, 23-24 terms a "bull's-eye approach" to discernment from the Bible). The biblical texts namely contain holy truths, which are universally applicable; hence, an idea, verse or even a word from the Word can be taken over as is from the text, to answer (even just on the sound of it) any given modern or personal question. This is done by for instance "pattern matching": seeking parallels or "resonance" between the Bible and the reader (Malley 2004: 152-156) in order to experience the personal relevance of the text.

The discernment of God's will is still not always equally easy, though; it may at times require substantial human effort. This includes two main challenges on the part of the reader: that the correct text from the Bible must be sought, and that I as reader should then be open to the truth, which may be an inconvenient truth, God will give me as the answer to my question. A very pious faith orientation is found here, namely a spirituality characterised by a sense of closeness to the Bible and, more specifically, to God (in more charismatic orientations, particularly to the Spirit of God), in the expectation - a deep trust that dare not be questioned, because it is foundational to such an intimately-personal religiosity - that God shall provide.

\subsection{The optimistic pessimist's way}

In a more pragmatic, informed Christian wisdom approach (Horton 2009:10) to discernment and the Bible, Scripture and reason are combined to seek God's will, rather than a set-in-stone plan of God for one's life. Here, thus, less of a hard-and-fast approach is found, in two respects: the constant mystery of finding God's will expressed is accepted (though seldom in such spiritual terms as used here), and greater openness is kept on where such "inspiration" may come from. The influence of tradition, culture, the mind, feelings and the like are openly acknowledged, although usually strongest adherence is pledged to the Bible as God's preferred channel of communication, or to the experience of the Holy Spirit in more charismatic faith expressions (yet, then, always still with strong adherence to the Scriptures as mediator or as carrier or as critical vehicle of the revelation of God's intent). Hermeneutics have however been taken note of here, and such awareness is incorporated into the sense of expectation to discern God's will.

In this kind of spirituality, the piety of a closeness to God may very well still be professed. However, education and serious engagement with the difficult questions of life (such as on suffering, death, the limits of the human condition) mean that such confessions are stated more subtly, with greater nuance and circumspection. Realism, even pessimism, has mitigated unbridled optimisms on the where and the what of finding God's will. Discernment is possible, but difficult; yet important.

\subsection{An arena of contestation (the most recent development)}

Over recent decades there have been different developments in Bible scholarship that have made much of the biblical text as "sight of struggle". One prominent strand of understanding the Bible texts in this way has come from so-called tertiary or genitive theologies: theologies of freedom, feminism, ecology, the poor, and so forth. In this broad approach, two branches are found (cf. Lombaard 2008:144-155): the most prominent one, springing influentially from Latin American liberation theology but now most prominent in feminist theology, takes a hermeneutical route, in which oppression and social exclusion both within the Bible texts and in the later use of the Bible to sanction unjust practices, are exposed, in a quest towards greater 
social justice. The other, more exegetical orientation, though with similar or parallel intentions, and with which Gottwald (1985) and Albertz (1992a \& 1992b) have been the most influential in theologically educated circles, seeks to study the text of particularly the Old Testament from within the framework of class or group analysis.

All these "sight of struggle"-approaches share the characteristic that they have opened exegetical eyes to the sociological and theological diversity within ancient Israel, which finds reflection within the texts of the Old Testament. The modern kind of spirituality that intersects with these awarenesses tend to be highly trained and thoroughly ecumenical, even interreligious. The commitment to the own faith, or the own denomination, may well still be strong, but the relativity associated with such preferences are acknowledged, or at least in some vague way felt. Differences are accepted, even appreciated; the healthy nature of contestation and of contextualisation trumps to such minds the idea of universal truths in any hard sense. In a paradoxical way (i.e. contrary to expectations from conservative or evangelical circles), precisely because such a broader, at times almost universalist, orientation is accepted by these individuals, a personal inclination towards matters of faith remains possible. The one is not lost within the many, but in some ways draws meaningfully from such diversitylt is this last, newer form of understanding the Bible and of searching for one's relation to it, that holds greatest promise for analysing discernment in particularly the Old Testament most fruitfully, given the diversities and the developments in religious history (Religionsgeschichte) encompassed within the Hebrew Bible. It is therefore this aspect that will next be explored in greater detail.

\section{IN CONCLUSION}

The phenomenon of discernment is of great importance not only for believers, but also for the discipline of Biblical Spirituality, both as it seeks to serve its constituencies, and for itself, in refining further the academic protocols of this relatively new discipline. The two faces or outlooks or mirrors that metaphorically convey the stance of this discipline, affirms the latter directly. Very important, furthermore, before attempting a fuller Biblical Spirituality of discernment, is to lay the methodological groundwork, some of which was attempted in this contribution. To do so as a dedication to Vincent Brümmer, is indeed a privilege.

\section{BIBLIOGRAPHY}

Agnew, U 2008. Transformative reading, in Agnew, U, Flanagen, B \& Heylin, G (eds) 'With wisdom seeking God'. The academic study of spirituality. Louvain: Peeters, 187-197.

Albertz, R 1992a. Religionsgeschichte Israels in alttestamentlicher Zeit 1 (ATD Grundrisse zum Alten

Testament 8/1). Göttingen: Vandenhoeck \& Ruprecht.

Albertz, R 1992b. Religionsgeschichte Israels in alttestamentlicher Zeit 2 (ATD Grundrisse zum Alten

Testament 8/2). Göttingen: Vandenhoeck \& Ruprecht.

Anderson, WL 2011. The discernment of spirits. Tübingen: Mohr Siebeck.

Berthoud, P 2010. Discerning spirituality: biblical and reformed perspectives. European Journal of Theology 19/1, 50-62.

Bertrand, D 2003. Le creuset Alexandrin du discernement des Esprit. Théophilyon VIII/2, 487-451.

Brümmer, V 2011. Wat doen ons wanneer ons bid? Oor die aard van gebed en geloof. Wellington: BybelMedia.

Brümmer, V 2010. Spirituality and the hermeneutics of faith. HTS Teologiese Studies / HTS Theological

Studies 66/1, Art. \#891, www.hts.org.za/index.php/HTS/article/viewFile/891/943.

Brümmer, $\vee$ 2008. What are we doing when we pray? (Revised and expanded edition). Aldershot: Ashgate. Brümmer, V 2006. Mysticism and union with God, in Brümmer, V (ed.) Brümmer on meaning and the

Christian faith. Collected writings of Vincent Brümmer. Aldershot: Ashgate, 317-331. 
Brümmer, V 1992. Speaking of a personal God. An essay in philosophical theology. Cambridge: Cambridge University Press.

Brümmer, V 1988. Alzo lief heeft God. Overdenkingen over Gods omgang met de mens. Kampen: Uitgeversmaatschappij J.H. Kok.

Brümmer, V 1984. What are we doing when we pray? A philisophical enquiry. London: SCM Press Ltd.

De Villiers, PGR \& Pietersen, LK 2011. The Spirit that inspires: perspectives on Biblical Spirituality (Acta Theologica Supplementum 15). Bloemfontein: SUN MeDIA.

De Villiers, PGR, Kourie, CET \& Lombaard, C (eds) 2008. The Spirit that empowers: perspectives on spirituality (Acta Theologica Supplementum 11). Bloemfontein: University of the Free State Press.

De Villiers, PGR, Kourie, CET \& Lombaard, C (eds) 2006. The Spirit that moves: orientation and issues in spirituality. (Acta Theologica Supplementum 8). Bloemfontein: University.

Dubay, T. 1997. Authenticity. A biblical theology of discernment ( $2^{\text {nd }}$ ed.). San Francisco: Ignatius Press.

Gottwald, NK 1985. The Hebrew Bible. A socio-literary introduction. Philadelphia: Fortress Press.

Guillet, J 1970. Sacred Scripture, in: Guillet, J, Bardy, G, Bardy, F, Vandenbroucke, JP \& Henri, M (eds) Discernment of spirits. Collegeville, MN: Liturgical Press, 17-53.

Hanson BC 1990. Modern Christian spirituality. Methodological and historical essays. Atlanta: Scholars Press.

Horton, DJ 2009. Discerning spiritual discernment: assessing current approaches for understanding God's will. The Journal for Youth Ministry 7/2, 7-31.

Howard, EB 2000. Affirming the touch of God. A psychological and philosophical exploration of Christian discernment. Lanham, Maryland: University Press of America.

Janowski, B \& Stuhlmacher, P 2006. Der leidende Gottesknecht: Jesaja 53 und seine Wirkungsgeschichte: mit einer Bibliographie zu Jesaja 53. Tübingen: J.C.B. Mohr.

Johnson, LT 1996. Scripture \& discernment. Decision making in the church. Nashville: Abingdon Press.

Lienhard, JT 1980. On "discernment of spirits" is the early church. Theological Studies 41, 505-329

Lombaard, C 2012/2013a. Discernment: context, orientation, definition (paper from keynote presentation at the "Religious Experience and Tradition International Interdisciplinary Conference", Vytautas Magnus University, Kaunas, Lithuania, 11-12 May 2012). To be published in Acta Theologica 2013, special edition on discernment.

Lombaard, C 2012/2013b. Discernment and Biblical Spirituality - an application: Discernment in the milieu and wake of Nehemiah 8 (paper from presentation at the "Experts Meeting on the Spirit and Discernment in Hebrew and Christian Scriptures", Carmelite Institute Mdina, Malta). To be published in Acta Theologica 2013, special edition on discernment.

Lombaard, C 2012a. Om die Skrif tot stilte te bring... Gewaarwordinge oor Afrikaanse Bybelse spiritualiteit (Inaugural lecture: Christian Spirituality, University of South Africa, 1 March 2012). Litnet Akademies, forthcoming.

Lombaard, C 2012b. The Old Testament and Christian Spirituality. Atlanta, Georgia: Society for Biblical Literature.

Lombaard, C. 2011. Biblical Spirituality and interdisciplinarity: the discipline at cross-methodological intersection. Religion \& Theology 18, 211-225.

Lombaard, C 2008. The relevance of Old Testament science in/for Africa: two false pieties and focussed scholarship. Old Testament Essays 19/1, 144-155.

Malley, BM 2004. How the Bible works. An anthropological study of evangelical biblicism. Walnut Creek: Altamira Press.

McGrath, AE 1999. Christian Spirituality. An Introduction. Oxford: Blackwell,

Moberly, RWL 2006. Prophecy and discernment. Cambridge: Cambridge University Press.

Munzinger, A 2007. Discerning the spirits. Theological and ethical hermeneutics in Paul. Cambridge: Cambridge University press.

Nolan, A 1982. Biblical Spirituality. Springs: The Order of Preachers (Southern Africa).

Panicola, MR 1999. Discernment in neonatal context. Theological Studies 60, 721-746.

Ruthenberg, TJ 2005. Contemporary Christian Spirituality: its significance for authentic ministry (DTh Christian Spirituality dissertation). Pretoria: University of South Africa.

Schneiders, S 2005. Biblical foundations of spirituality, in Mahoney, EJ (ed.) Scripture as the soul of theology. Collegeville: Liturgical Press, 1-22. 
Schweizer, E 1989. On distinguishing between spirits. The Ecumenical Review 41, 406-415.

Ukpong, JS 1989. Pluralism and the problem of the discernment of spirits. The Ecumenical Review 41, 416-425.

Von Rad, G 1962. Theologie des Alten Testaments (Band 1; 4. Auflage). München: Chr. Kaiser Verlag. Vosloo, W 1983. Rûah/gees in die Ou Testament. Skrif en Kerk 4/2, 40-68.

Waaijman, K 2011. Biblical Spirituality: an "other" reading (allègoria), in: De Villiers, PGR \& Pietersen, LK (eds). The Spirit that inspires: perspectives on Biblical Spirituality (Acta Theologica Supplementum 15). Bloemfontein: SUN MeDIA, 1-20.

Waaijman, K 2004. Mystiek in de Psalmen (Mystieke teksten en thema's 22). Baarn: Uitgeverij Ten Have.

\section{KEY WORDS}

Biblical Spirituality

Discernment

Old Testament

Text-reader interaction

Mysticism

\section{TREFWOORDE}

Bybelse Spiritualiteit

Onderskeiding

Ou Testament

Teks-leser interaksie

Mistiek 